\title{
Logistics Cost Management from the Supply Chain Perspective
}

\author{
Yu Gu, Shaojian Dong \\ Beijing Materials Institute, Beijing, China \\ Email: dsj7420892@126.com,1078925848@qq.com
}

Received 20 April 2016; accepted 18 June 2016; published 21 June 2016

Copyright (C) 2016 by authors and Scientific Research Publishing Inc.

This work is licensed under the Creative Commons Attribution International License (CC BY). http://creativecommons.org/licenses/by/4.0/

(c) $\underset{\mathrm{EY}}{\mathrm{i}}$ Open Access

\begin{abstract}
With the increasingly fierce market competition, China has more sound market economy system. Competition in the market price on the important position of the company is also increasing. It increases its profit source which can provide third-party logistics services business. Third-party logistics enterprises should put the customer requirements on an important position and meet the requirements of customers with the lowest prices. Our third-party logistics companies should know as soon as possible about the process of supply chain operations, and actively involved, starting from its own characteristics. And our third-party logistics companies control the entire supply chain from the perspective of the total cost of logistics companies. To accelerate the development of cost control and improvement, our third-party logistics companies improve their competitiveness, become a very important sector of our economy and the development of new economic growth point, build closer cooperation between the various companies in the supply chain and achieve long-term development.
\end{abstract}

\section{Keywords}

Supply Chain, Lowest Price, Logistics Companies, Long-Term Development

\section{Introduction}

In recent years, increasing competition, specialization is growing. Many companies choose to outsource their logistics requirements, accompanied by the rapid development of e-commerce, so the speed of the logistics company's development is greatly accelerated. The rapid development of the logistics industry not only accelerates the delivery speed of goods and capital flow, but also improves the circulation speed of logistics and the economic growth rate. In order to maintain the rapid and healthy development of the logistics industry, countries introduce a number of incentive measures and policies. However, there is considerable room of development for 
China’s logistics industry compared with European and American countries.

The logistics industry in China starts relatively late. The technical level of the logistics industry is not high and the hardware is not good. As a result, China's logistics companies have higher logistics costs and lower profit margins. There is no strong competitive advantage.

\section{Literature Review}

Joseph Sarkis (2012) pointed out that the composition of the supply chain cost theory consists of three aspects, namely, cost, relations and products, and established the corresponding frame system which consists of three levels: transaction costs, operating costs and direct costs [1].

Viswanath Cvsa (2014) proposed the supply chain and even the finished products and raw materials connected [2], and sold finished products to consumers a versatile network tool.

Song Hua extensively researches the costing accounting method about enterprise logistics [3] that can be applied in the logistics cost accounting. Logistics cost accounting is particularly suitable distribution industry and manufacturing industry, but there are not a lot of studies on the costs of third-party logistics control.

\section{Logistics Enterprise Cost Control Situation}

Our introduction of foreign logistics time is relatively late, and the company's efficiency is speeding up because there are more and more logistics companies. So the company can concentrate on the technology research, which not only improves the technical level, but also improves the overall speed of development. Along with a lot of large foreign logistics companies appearing in China's logistics market, the competition in the logistics industry is also virtually increased. Of course, the development of domestic logistics companies has also been accelerated. And due to the lack of some resources, many production companies do not want to put a lot of manpower, material and financial resources on logistics services. Logistics outsourcing generally puts its own core technology into more energy, or innovation [4]. At present, most of logistics company is small, only putting the rapidity, safety and reliability of the storage, transportation and other services into account, putting in less logistics cost into consideration, Simultaneously, they also did not think about the progress of the entire supply chain, so the logistics cost effective control is very important. However, there are many problems in our country. A lot of logistics cost methods used and the degree of cost control, resulting that there is a high cost about logistics enterprises, a great problems need to be solved.

\section{Logistics Enterprises in Cost Control Problems on}

\subsection{There Is No Perfect System of Cost Control and Cost Accounting Industry}

Many logistics companies cannot calculate the cost accurately. There are still many problems. It should be carried out on a cost analysis and calculation of consumption in each link. Most companies do the costing in the Ministry of Finance and is reflected in the table, but in fact the company is not easy to control its logistics costs. Logistics companies transfer logistics costs to an independent logistics company, so they can control the company logistics cost components. It can be based on market conditions and market competition to bid, and thus cooperate with most cost-effective logistics companies, the company will generally reduce their workload and labor costs, not only reduce costs but also reduce the time, perhaps it can increase efficiency, maximize profits and maximize enterprise value.

\subsection{Cost Control Is Not Effective}

Recent survey data indicate that domestic logistics company's profit margin is less than $1 / 3$ of the international logistics company. Domestic logistics companies are simply not only the existence of high logistics costs, but also there is not quickly reducing speed. Another reason resulting in high logistics costs is that many logistics companies will not consider a company's supply chain operations analysis into account, and the general logistics companies cannot consider the overall supply chain, so that they cannot do well in the middle of the supply chain cost control, including warehousing costs and shipping costs. Throughout the supply chain, logistics companies did not use the best way to arrange for the delivery process, which resulted in short positions departure, detour traffic, repeated situation, delivery and the increase of the cost of the loss. At the same time, there are many sectors about the entire supply chain. Just one of the links did not do that. It will be difficult to achieve the 
target of logistics companies. Business will stop in the supply chain. Companies will be unable to meet customer requirements. It will result in the loss of client.

\subsection{No Idea of the Whole Process of Cost Control}

Now, many corporate managers cannot fully understand the importance and logistics cost control. It has not yet formed the concept of modern logistics. There is a lack of comprehensive understanding in this regard. Company executives did not pay sufficient attention to the concept of logistics cost control and failed to form awareness of modern logistics. There are some simple articles on management, storage and transportation as well as some other simple operations. There is no comprehensive grasp. Therefore, company executives should fully grasp cost control system, particularly in the supply chain, and grasp the details on the macro system, which costs control.

\section{On Safeguards Logistics Companies Supply Chain Cost Control Programs Implemented}

\subsection{Improve the Quality of Personnel throughout the Logistics Industry}

In the context of Chinese logistics cost management companies, the company's team members who are adapted to couple and training can better achieve the supply chain logistics cost management._To achieve the company's supply chain logistics cost management, we need early training in all sectors of the operator, in order to maximize the use of company information in the supply chain software. Only reasonably coordinating with the network technology and computer systems, supply chain logistics system can make between the various departments of the company and between different companies of the whole complex in order to put sales, customer service, and other aspects of production and order into coordination.

Companies need to change the previous mode of operation between departments, namely, supply chain integration. But in the short term, the company is not easy to implement this concept. In order to promote the timeliness of completion, and make a tight fit between the various departments to promote each employees in the subconscious, they can have a supply chain management philosophy, enhance company subsequent training on staff, while allowing team leaders play their exemplary role, active participation and cooperation in all aspects of the implementation, as long as all team members carry out their duties, and closely cooperate in order to implement the cost of logistics enterprises to control fundamentally.

\subsection{The Formation of Integrated Supply Chain Cost Control Concept}

Logistics companies are not only to implement cost control within the company, but also to control the external environment in the relevant companies, through cooperation between the supply chain logistics company to complete cost control. Logistics company itself determines systemic systemic logistics costs, so that the company's cost control key point is to minimize the total cost of logistics [5], rather than the lowest cost of an individual, a company should have been carried out using the control assembly logistics company's logistics management, and control over the supply chain.

By forming the space and time effect, the goal of cost control is positioned as the lowest total cost of logistics, so to maximize the value of logistics services. Logistics companies want to achieve the goal of cost control, balance the relationship between the cost of logistics and get maximum of logistics performance. The logistics get the maximum performance. It should be on the integration of the company's various logistics resources, choose the way the whole process of logistics costs in the supply chain from the point on the control.

\subsection{Enables Industry to Improve Cost Control System}

Now, most of the logistics cost control system contains only a single logistics company's logistics cost control, not only inadequate but also single, and in the supply chain logistics cost control, not only to make Coordinate between the companies in the supply chain, but also be suitable single company use, so that the logistics supply chain achieves the goal of integration. Logistics supply chain cost control angle is not the same with a single logistics cost control and is to consider the entire supply chain from the each company's logistics supply chain that has done through third-party logistics companies. There should be a specific cost control system management 
and constraints.

Depending on the logistics company's specific circumstances, the nature of the company and the company scale will have different supply chain processes, and thus have a different supply chain strategic objectives, using different costing methods. This article is carried from the perspective of the supply chain logistics company under the control of costs, and analyzes the cost of control about logistics companies from global and local perspectives on departure, only to get the whole supply chain starting, so logistics companies can better control the cost of logistics companies. Therefore, it should perfect the industry's cost control system, and depending on the needs of the entire supply chain activities to be decomposed logistics resources with Activity Based Costing, which can be focused analysis, for the corresponding results, it can obtain specific cost control programs, and evaluate the specific programs.

\section{Conclusion}

With the rapid development of China's logistics company, a sharp increase in the number of supply chain logistics integration theory becomes a hot topic. Logistics companies should depart from its own characteristics, to control the total cost of the logistics company's entire supply chain from the perspective of cost control to accelerate development and improvement, thereby it can increase their competitiveness. Let it become a very important industry in Chinese economic development and new economic growth point. Simultaneously, logistics companies should reduce their own costs, closely contact with all companies in the supply chain, partnership, mutual assistance, mutual benefit and reciprocity. Logistics companies in the implementation of cost control should not be just a partial implementation of the logistics cost control, but also in the entire supply chain from the point of view, all-round, the whole process of analysis to control the total cost of logistics companies, making the whole process of the entire supply chain. It can also be an effective control and supervision of the entire total cost of logistics.

\section{Funding}

Beijing Materials Institute research support funds (0541604904) funding.

\section{References}

[1] (2014) Song China Based Logistics Cost Accounting and Management of the Supply Chain Process. Renmin University of China, No. 3, 1-5.

[2] Fen, C.Y. and Zeng, X.F. (2013) Innovation Supply Chain Logistics Management Process. Logistics Technology, No. 1, 21-25.

[3] Zhang, S. and Lu, Z. (2014) Logistics Cost Management on Supply Chain Analysis. Accounting Communications, No. 3, 44-49.

[4] Li, Y. (2012) City Logistics Cost Control and Optimization of the Economic Structure: Evidence from the World. Shanghai Economic Study, No. 7, 57-60.

[5] Lambert, D. and Stock, J. (2013) The Global Supply Chain Forum in Fundamentals of Logistics Management. The Ronald Press Company, Boston, 80-85. 


\section{Submit or recommend next manuscript to SCIRP and we will provide best service for you:}

Accepting pre-submission inquiries through Email, Facebook, Linkedin, Twitter, etc A wide selection of journals (inclusive of 9 subjects, more than 200 journals)

Providing a 24-hour high-quality service

User-friendly online submission system

Fair and swift peer-review system

Efficient typesetting and proofreading procedure

Display of the result of downloads and visits, as well as the number of cited articles

Maximum dissemination of your research work

Submit your manuscript at: http://papersubmission.scirp.org/ 